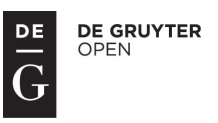

\title{
Contractual Penalty and the Right to Payment for Delays Caused by Force Majeure in CZECH CiviL LAW UNDer THE NeW Civil CODE
}

\author{
Martin Janku ${ }^{1}$
}

\begin{abstract}
In the context of the conclusion of contracts between entrepreneurs under the Czech Civil Code, it is a relatively common arrangement that the parties disclaim any and all liability for damage arising from non-compliance with contractual obligations, if they can prove that this failure was due to an obstacle independent of their will. This circumstance excluding liability for the damage is called force majeure by the theory. In many countries this circumstance is ruled upon directly by the legislation (höhere Gewalt, vis major). The Czech regulations represented by the new Civil Code of 2012 (CivC), however, contains only a framework provision that mentions discharging reasons. The paper deals with the - rather disputable - issue that the force majeure does not affect the obligation to pay a contractual penalty under the new rules of the CivC. It should be therefore reflected in the arrangements for contractual penalties inter partes. To this effect the paper analyses the concepts of contractual penalties and force majeure in civil law legislation. Afterwards it compares their mutual relationship and impact on the obligations of the Contracting Parties. Finally, it draws recommendations for practice from the perspective of the contracting process.
\end{abstract}

\section{Keywords}

Circumstances Excluding Liability, force majeure, Contractual Penalty, Delay in Contract Performance

\section{Introduction}

In the context of the conclusion of contracts by entrepreneurs governed by civil law (ius privatorum), it is relatively common that the Parties agree on arrangements to disclaim any liability for damage arising from failure to comply with contractual obligations, if they

\footnotetext{
${ }^{1}$ Department of Law and Social Sciences, Faculty of Business and Economics, Mendel University in Brno, Zemědělská 1, 61300 Brno, Czech Republic. E-mail: jankum@mendelu.cz.
} 
can prove that the latter was due to an obstacle entirely independent of their will and in respect of which they could not be reasonably expected - at the time of conclusion of the contract - to face such obstacles and to eliminate or overcome them if they arise.

The above circumstances excluding liability for damage are called cases of force majeure by the theory. In many countries this circumstance is ruled upon directly by the legislation (höhere Gewalt, Act of God - e.g. Section 7 (2) of the German Strassenverkehrgesetz, of 5 May, 2003, BGB1. I S. 310 or the French Act No. 85-677 of 5 July, 1985). The circumstances representing force majeure constitute situations where a breach of a legal obligation occurs due to unforeseeable, irresistible and irreversible obstacles, independent of the will of the principal. The norms in the Czech law covering the circumstances excluding liability for damage (Section 374 of the Commercial Code) were withdrawn without the provision of adequate replacement regulation in the new Civil Code, which contains, in Section 2913/2, only a rule on the cause of liberation.

According to Section 300 (now withdrawn) of the Commercial Code, the circumstances excluding liability (including cases of force majeure) had no effect on the obligation to pay mutually-agreed contractual penalties. It was and still remains disputable as to whether or not the breach of the obligation due to cases of force majeure leads automatically to the extension of the period for the fulfilment of obligation. The question under examination is that such cases, excluding a breach of contractual obligation, will also lead to the exclusion of the obligation to pay a contractual penalty.

\section{Methodology and objectives}

The consequence of circumstances excluding liability for damage does not lead to the extinction of the obligation to pay contractual penalty was not included in the new rules on the contractual penalty contained in the Act No. 89/2012 Coll., Civil Code (hereinafter "CivC"). This circumstance may have influence on the obligation to pay a contractual penalty (i.e. the penalty will not be refunded), although we cannot yet give a definite answer to this question, at least until some case law on this issue is settled. Section 2913 (1) and (2) CivC, which relate only to the obligation to pay damages (not to pay the contractual penalty), could, however, suggest a completely opposite interpretation.

The present paper deals with this disputable problem that should be consistently ruled by all treaty arrangements concluded inter partes and concerning contractual penalties. The paper first analyses the concepts of contractual penalty and force majeure in the valid legal rules, and then places them by way of comparison in mutual relation and determines how they may impact the obligations of the Contracting Parties. In the conclusion of this comparison, the paper formulates recommendations for Contracting Parties finding themselves in the process of concluding contracts. 


\section{Contractual penalty - notion and legal regulation}

Contractual penalty is an important tool of contract law with regard to the assertion of debts. Its function is not only to secure the debt (as in the case of a guarantee), but to otherwise strengthen the position of the creditor (Švestka, Dvořák, Fiala, Pelikánová, 2014). According to the authors of a former commentary on CivC (2002), it is the "written side agreement of Contracting Parties in which one of the Parties undertakes to provide the other Party with a special, specifically defined performance in the case it breaches one of its contractual obligations" (Holub et al., 2002). According to other authors, a more practical definition notes that a contractual penalty is the "financial amount that the debtor is obliged to pay the creditor in the case of not fulfilment of his contractual obligations, this regardless of whether the obligation breach has caused a damage to the creditor" (Škárová in Jehlička et al., 2006). As such, the penalty is an effective tool to increase the legal certainty of creditors in contractual relations.

The new CivC takes over the provisions of the rules hitherto contained in CivC 1964 (Sections 544 and 545), and also the Commercial Code (hereinafter "ComC") (Section $300 \mathrm{ff}$.); however, it adds certain clarifications. The contractual penalty is an independent property right that the Parties must agree upon. Thus, it is not an accessory to the contract obligation, as is, e.g. interest on delay in payment of a monetary debt. However, its existence depends on the existence of the main (primary) obligation - the duty to pay a contractual penalty adheres to the violation of the latter. Should there be no legally valid arrangement of the main obligation (e.g. for the nullity of the contract), there can also be no violation of the contract duties and, accordingly, the contractual penalties cannot enter into effect. The contractual penalty also cannot be claimed in the event that the primary obligation ceases to exist due to preclusion. More problematic is the situation where the main contractual obligations terminate due to withdrawal from the contract by a Party. In this case the rights and obligations of the contract shall cease to exist. However, should the obligation have been breached before the withdrawal, the creditor shall be entitled to the contractual penalty even after the termination.

Within the meaning of the confirmation of the abovementioned dependence of the contractual penalty, one of the judgments of the Supreme Court of the Czech Republic (1998) states that "the obligation from the agreement concerning contractual penalty is an accessory obligation, therefore its existence and consequences are tied with those of the primary contract obligations. If the primary obligation does not arise, the accessory obligation cannot enter into effect, as it was determined to secure the fulfilment of the contractual obligations" (NS ČR, 2Odon 90/97, 1998).

From the substantial point, the contractual penalty can be agreed upon to cover the breach of any contractual obligation. The point is to exactly specify the duty the implementation of which is secured by the contractual penalty. The agreement on contractual penalty can contain either a reference to a particular obligation, the breach of which shall be sanctioned by a contractual penalty, or a more general formulation, referring to the preceding Contract provisions - however, it is essential to mark exactly the obligation in question in order not to be confused with the obligation not secured thereby. 


\section{Notion of force majeure - definition and purpose}

The Contracting Parties shall conclude contracts primarily in order to fulfil their obligations. Performance of the contract is the intention of the parties, and is a desirable result at the time of the conclusion of the contract for its all participants. During the existence of the contract, however, circumstances can occur which are capable of affecting the implementation of contractual obligations. The Parties may - by means of detailed contract negotiations - restrict the impact of these negative circumstances and/or specify how their occurrence will be dealt with. To deal with the impact of some specific negative circumstances on the implementation of contractual obligations, and, especially, to exclude the liability for the damage caused as a consequence of these circumstances, definition of the force majeure clause has been established.

Circumstances of force majeure are, in general, circumstances that exclude the liability of the parties for failure to comply with the obligations resulting from the contract. The kind of obligation where - in the case of force majeure - the Contracting Party shall be exempted and what is the influence of such a situation on the concrete level of its liability, must be assessed in accordance with the legal provisions in force and, mainly, according to the will of the Parties to the relevant contractual relationship. This circumstance occurs, as a rule, after the conclusion of the contract and is independent of the will of the parties, is unpredictable and cannot be avoided by them. This circumstance entirely or almost entirely excludes the performance of the contract.

The importance of the force majeure clause lies mainly in the fact that "this clause relieves the Party that fails to meet duly and on time its contractual duties, the obligation to compensate for damage sustained by the other Party as a result of the non-compliance" (Střelec, 2003). It should be noted that the force majeure clause may not relieve the Party only from the obligation to compensate for the damage, but it can also relieve the latter from other obligations, inter alia, from the payment of contractual penalties. The force majeure clause is therefore the so-called exempting (exonerating) clause, which relieves the Party from liability in particular cases and constitutes an exception to the principle pacta sunt servanda in favour of the principle rebus sic stantibus (Chengwei, 2003).

The force majeure clause reflects generally the uncertainty of the Contracting Parties which is always present when formulating as well as, subsequently, implementing the contract provisions. An appropriate contract provision can, nevertheless, reduce uncertainty to a more bearable limit, because thanks to the proper construction of the force majeure clause, each Party will have more certainty with regard to some of the key issues. Among the latter may, inter alia, belong

- What are the new obligations between the Parties if circumstances of force majeure occur?

- Which events are considered to be cases of force majeure?

- What influence will these events have on the obligations of the Contracting Parties?

- What happens to the contract itself?

The force majeure clause is ruled upon by national legislation and international normative treaties, as well as by so-called soft law provisions. None of these rulings, however, 
contains an exhaustive enumeration of situations considered to be force majeure. As a rule, the provisions are of a dispositive character, and specify in very general terms what can be considered the act of force majeure. It is therefore always in the last instance the will of the Parties that - preferentially by the way of demonstrative enumeration - provide in the contract for specific cases which can be considered force majeure (commercial and trade contracts contains a rule that the provisions on cases to be recognized as force majeure are kept as part of the General Conditions on Delivery).

Since it is not clear what circumstances can generally be considered cases of force majeure, theory and practice have together arrived at a draft list of some typical circumstances consistently considered cases of force majeure. Among these are:

- war, revolution, pirate attacks, civil unrest, sabotage

- terrorist attacks,

- natural disasters (e.g. earthquake, flood, storm, volcanic eruptions, tsunami, fire)

- state power invasion hindering implementation (embargo, boycott)

- strikes.

Other situations are not obviously obstacles of a force majeure nature. Therefore, it is desirable and mostly required to specify in the contract itself as much as possible situations eligible for force majeure status in order to reduce the uncertainty of the parties to the maximum amount. Other circumstances of force majeure, in which, however, there is no general consensus, are electric power outages, loss of oil supplies, amendment of legislation serving as the basis for the contract performance etc.

The regulation of force majeure is also related to the question of the extent to which the obstacle intensity must be reached in order to classify it among the latter. Generally, the circumstances of force majeure constitute an obstacle of such intensity that it makes the performance either totally impossible or so difficult that it becomes near to impossible (Rozehnalová, Střelec, Sehnálek, Valdhans, 2004).

\section{a) Force majeure creates an objective (external) impossibility with regard to performing the obligation}

External circumstances typically occur in cases where there is a condition that makes, in general, compliance with a specific contractual obligation impossible for any person, not only for the Contracting Party concerned. So, for example, there will be no external circumstance should a prohibition on the export or import of certain goods be addressed only to the concerned Contracting Party but not imposed in general. Therefore, it is very difficult to consider as cases of force majeure events resulting in the illness or disability of the Contracting Party, since in many cases this person may be - for the performance of contractual obligations - replaced by another.

On the other hand, administrative measures or measures wherein external circumstances affect the obligation to supply the subject-matter of the contract or pay its price can be considered force majeure. In these cases it is necessary to determine whether the 
obligation in question cannot be fulfilled otherwise ${ }^{2}$. However, the requirement of objective impossibility to fulfil the obligation cannot be interpreted as absolute, since in such a case, a circumstance of force majeure could, in principle, never occur, because even in the case of natural or social disaster this would, with a high degree of probability, not exclude that some person would be able to meet the obligation concerned.

That said, such an interpretation would certainly be contrary to the purpose of these provisions. The above requirement is rather to be interpreted in that the intervention of an external circumstance into the fulfilment of contractual obligations shall be of such character that a third person would not have been able to comply with these obligations under the same or similar intervention. This interpretation, however, must not be so wide in the case of a general and relatively easily determinable subject-matter of the contract. In any case, due to the impact of external circumstances on the contractual obligations, the performance of the latter must become impossible and not only be aggravated. This condition, i.e. whether the impact of the external circumstances only limits or directly prevents the fulfilment of the contractual obligations, must be carefully assessed, e.g. in the case of administrative measures of the state (new legislation passed by the state).

However, the question arises whether, in the case of new legislation that formally only restricts the performance of the contract, but in fact determines such conditions that are in practice impossible to meet, or feasible only at the cost of incurring exceptional extra costs, the conditions of force majeure would be fulfilled.

\section{b) Force majeure shall occur only after the contract comes to its existence}

The external circumstance must arise only after the conclusion of the contract. In our opinion, it is not absolutely necessary that the external circumstance occur only after the contractual obligations become due, since specific obligations may arise subsequently, for example as a result of a condition precedent. Otherwise an unsolvable situation would occur where a contract was concluded but individual obligations following thereof would be bound to meet either objective circumstances or other conditions (typically the opening of a letter of credit, conclusion of a contract of insurance, export credit, etc.), whereby in the meantime, since the contract conclusion and meeting the condition, a case of force majeure would occur - but, of course, as this was already before the emergence of the contractual obligations (this arises only upon the meeting of the precedent conditions), this external circumstance did not have the required contractual consequences on the specific contractual obligation.

Therefore, the occurrence of the external circumstance is to be bound to the conclusion of the contract, or, even better, to the moment when the contractual obligations are validly negotiated but still may not be effective, i.e. Contracting Parties are not obliged to comply with them.

\footnotetext{
${ }^{2}$ For example, the Tribunal of International Commercial Arbitration at the Russian Federation Chamber of Commerce and Industry stated in its decision of 06.10.1998 that even the bankruptcy of the Bank through which the buyer should make payment, although this was not a circumstance caused by the seller, shall be without prejudice to buyer's obligation to pay the purchase price, and neither shall in any way affect the obligation to compensate for damage caused by its delay (See Tribunal of International Commercial Arbitration at the Russia Federation Chamber of Commerce, No. 269/1997 of 06.10.1998, CLOUT Case No. 464).
} 
For those events when the external circumstance precedes the formation of contractual obligations, there are no legal consequences for that particular relationship. While it is not possible to ignore this circumstance, as with, e.g. some administrative measures, obviously, it cannot have the same consequences as it would have in the case when the external circumstance arises after the formation of the contractual obligations. Although the performance of the contract would be impossible, we can imagine that in this case the other contracting Party will at least seek damages caused by the fact that it has assumed the fulfilment of the contractual obligations. Such damage may consist at least of the costs incurred for the conclusion of the contract and/or other expenses incurred by presuming the performance of the contract by the other Contracting Party.

If there was intervention by an external circumstance prior to the formation of contractual obligations then, on the other hand, the difference in time between those moments has to be assessed. It may actually happen that - particularly with large international contracts the contract is concluded at a place that bears no relationship to its performance, and the parties concluding the contract may not be aware of the latest information. Consequently, they would not know that the subject-matter of the contract is impossible to be met because circumstances of force majeure had occurred in the place of its fulfilment (production plants flooded, breakout of social unrest, etc.). Therefore, although the external circumstance typically belongs among force majeure events, in the case of a small time gap between the occurrence of the obstacle and the formation of the obligation (or its valid negotiation), it is then necessary to evaluate the knowledge of its existence by the parties concerned. However, the length of the time gap has to be limited, with its upper limit being determined by the Contracting Party's proper care for its business and/or by the necessity of information about its activities and circumstances affecting it.

The relevance of this condition, consisting of availability of information on the external circumstances, may, however, be accepted only in the case of such circumstances that have significant impact on the performance of the core obligations arising from the contract, such as the manufacturing of the contract subject-matter, etc. Relevance may also be admitted only in the case of completely unforeseen external circumstances, typically terrorist attacks or a natural disaster (landslide, earthquake, etc.) that cannot be foreseeable.

\section{c) Conditions for application of force majeure}

The dissolved Czech ComC defined, in Section 374, circumstances that preclude liability for damage caused. The provision set down the basic conditions, namely:

- the circumstance is not caused by the party obliged

- unpredictability of the obstacles

- impossibility of its being overcome

Moreover, the circumstance excluding liability must be independent of the will of the party, inevitable, and, at the time of its occurrence, unpredictable and resulting in the prevention of the fulfilment of his obligations (Chalupa, 1993).

The obstacle concerned must prevent the Contracting Party in the fulfilment of its obligations arising from the contract. Therefore, it cannot be an obstacle that only makes the 
fulfilment of the obligations difficult (this purpose is, in particular, served by instituting hardship clauses). The impact of the obstacle thus must be very onerous to the fulfilment of contractual obligations. The circumstance of force majeure must make the fulfilment of the obligation permanently or temporarily impossible (Chalupa, 1993). It is necessary to realize that the above section of ComC ruled that an obligation to compensate for damage, and a time limitation for the duration of the obstacle, followed from the rule specified. In the case that the circumstances preventing the performance of the contractual obligation will persist only for a short period of time (for example, a general strike the extent of which will be in the order of hours) it would definitely not be justified to consider it force majeure. Some authors explicitly state that, in order to allow the application of this provision, the obstacle may be of a temporary character but it cannot be of a negligible period of time (e.g. Bejček, 1993). In events where the obligation to comply with a contract is permanently and completely destroyed, then, besides the application of a force majeure clause, other statutory provisions and/or contractual arrangements come under consideration and are also used to address this situation. Typically, for example, this may be the case with a natural disaster hitting the plant of a supplier, or hitting a construction site in the case of a contract for work or a contract for the supply of investment unit. However, it may also be a case of an obstacle that will be attached to the transportation of goods - e.g. where the goods are transported via a third state, the local situation of which makes it impossible to transport goods through its territory and which is the only option for transportation.

In relation to the timing of the occurrence of force majeure, some authors distinguish between two situations - cases when it occurs only after the formation of the contractual obligations, and cases of force majeure when the circumstance already arises before the formation of the contract, but as such was unforeseeable and unpredictable for the Contracting Parties (Chalupa, 1993). However, we hold this distinction to be misleading, as from the defined conditions for the applicability of the force majeure clause always follows the requirement of the unpredictability of the circumstances, and not only in those cases when contractual obligations were established after the occurrence of the aforesaid external circumstances. Any other conclusion could lead to absurd conclusions and situations. The condition of unpredictability must always be fulfilled, even in the case that the circumstance of force majeure arises only after the formation of the contractual obligations. The Czech Supreme Court went even further in its judgment, when it established that the degree of predictability must be in direct proportionality to the estimated professional care and due diligence of the other Contracting Party ${ }^{3}$. It is thus obvious that the obliged Contracting Party required to meet specific contractual obligations must also be equipped with specific knowledge or skills and is obliged, as a proper businessman, to make use of this knowledge and skills so as to comply with the contractual obligations. The authors also mention in relation to this that the unpredictability of the condition includes the assumption of certain professional skills to be assumed and included in the structure of the fulfilment of obligations regarding any minor fluctuations that may occur in any branch of business (Střelec, 2003).

\footnotetext{
${ }^{3}$ See Supreme Court of the Czech Republic, rozh 29 Odo 690/2001 of 08.01.2003.
} 
Despite the fulfilment of the above conditions, it is obvious that force majeure will not, with legal implications for the contractual relationship and obligations to compensate for damage, occur in all of those cases in which the above circumstances are met. The obstacles must be of such character that it can reasonably be assumed that the obliged party would have eliminated or averted the obstacle or its consequences. The assessment of the possibility of overcoming this obstacle is not based on current conditions on the part of the obliged party, but the latter shall be objectified by assuming whether this obstacle can be overcome due to the care that can be expected from any debtor in general. (Tomsa in Štenglová et al., 2009).

\section{Force majeure as a circumstance excluding obligation for payment of the contractual penalty}

For those cases of contract provisions where the Contracting Parties secured compliance with the contractual obligations through a contractual penalty, the new CivC stipulates an obligation to pay should a breach of its contractual obligations occur - even in cases where the breach occurred due to circumstances of force majeure. However, it is necessary to stress that the contractual penalty primarily has the character of lump sum compensation for damages, i.e. it compensates for the damages that the principal suffered as a result of the breach of contractual obligations. Nowadays, however, it is quite common that the provisions in question fulfil, in particular, a penal function and, therefore, the principal, in addition to the contractual penalty, is often entitled to the proper compensation of damage. In cases where the breach of contractual obligations occurred due to circumstances of force majeure, the obligation to compensate for damage shall not arise.

The quoted legal provisions thus do not preclude the duty to pay a contractual penalty in cases where a delay in the fulfilment of the contractual obligation has been caused by a circumstance of force majeure. This statutory provision has nevertheless a dispositive character, which means that the Contracting Parties can exclude this consequence inter partes. Then the obligation to pay the contractual penalty may share the statute of the obligation to compensate for damage so that in the case of a breach of contract obligations secured by contractual penalty that was due to circumstance of force majeure, the obligation to pay the contractual penalty will not arise. This limiting clause is, however, often forgotten in many contracts, which have special provisions to rule on cases of force majeure, and as a result "misunderstandings" between the Contracting Parties can arise when the obliged Party is surprised and displeased by the impact of the statutory provisions and will undertake all possible steps to eliminate its effects.

Further, the statutory regulation of the circumstances of force majeure does not in any way rule on the relationship between the force majeure and the fulfilment of the contractual obligation affected. This leads inevitably to the conclusion that the emergence of circumstances of force majeure shall in no way affect the obligation of the contracting parties to fulfil this obligation. The authors note on this issue that, unless the Contracting Parties have agreed otherwise, the contract obligations remain in force only with an additional period specified for their execution (Střelec, 2003). 


\section{Conclusion}

With reference to the above, it should be pointed out that the fragmentary statutory provisions and, in particular, the absence of an explicit regulation of force majeure and its legal consequences in the new $\mathrm{CivC}$ puts great emphasis on the contractual arrangements inter partes. The contracting parties must agree on the relationship of force majeure to the contract obligations affected by it, and, in the case of an arrangement of contractual penalties in the contract, what will be the effects of the force majeure on the repayment obligation, contractual fines in the event of a delay in the fulfilment of contractual obligations. Otherwise, a paradoxical situation may occur in which the obliged Contracting Party shall not be liable for damage caused by non-performance of the contract subject-matter due to circumstances of force majeure, but it continues to be obliged to perform the latter. For those cases in which the parties have omitted to rule on the relationship between the contractual fine and force majeure, the obliged Party would not be obliged to compensate for damages but, with regard to the provisions on the contractual fine, it would not avoid its payment.

Even if the Contracting Parties would not have ruled on the relationship of force majeure to the obligation to perform the contract, in the case of non-compliance with the contract obligations breaching the contract in a substantial way, the principal shall be entitled to withdraw from the contract, irrespective of whether the non-compliance was caused by the circumstance of force majeure or not. However, this right belongs only to the principal and not to the Contracting Party obliged to perform the debt, which is unable to withdraw from the contract.

In the conclusion of the present paper it has to be stressed that the issue of force majeure should not be confused with the impossibility of performance. The basic difference is considered to consist in the fact that force majeure is held to be a reason for the liberation from the obligation to compensate for damage, while the contractual relationship continues to exist, whereas the impossibility of performance has influence on the existence or non-existence of the contractual legal relationship itself and not only on the liability for damages.

\section{References}

Bejček, J. (1993). Odpovědnost za škodu v obchodních vztazích. Právní praxe, 41(9), 23-34.

Holub, M. et al. (2002). Občanský zákoník, komentář. Praha: Linde.

Chalupa, R. (1993). Náhrada škody, Obchod a právo, 1993(3), 3-11.

Chengwei, L. (2003). Remedies for Non-performance: Perspectives from CISG, UNIDROIT Principles \& PECL. 2003. PART V. EXCUSES. Retrieved from: http://www.cisg.law.pace.edu/cisg/biblio/chengwei-79.htm.

Rozehnalová, N., Střelec, K., Sehnálek, D., Valdhans, J. (2004). Mezinárodní obchodní transakce. Brno: Masarykova univerzita.

Střelec, K. (2003). Nepředvídatelné události v mezinárodním obchodním styku a nástroje jejich smluvní regulace. Obchodní právo, 2003(7-8), 57-68. 
Jehlička, O. et al. (2006). Občanský zákoník, komentář. 10th ed. Praha: C.H. Beck. Švestka, O., Dvořák, J., Fiala, J., Pelikánová, I. et al. (2014). Občanský zákoník. Komentár̆. 5th ed. Praha: Walters Kluwer.

Štenglová, I. et al. (2009). Obchodní zákoník. Komentář. 12th ed. Praha: C.H. Beck. Tribunal of International Commercial Arbitration at the Russia Federation Chamber of Commerce, Judgement No. 269/1997 of 06.10.1998, CLOUT Case No. 464 (UNCITRAL Digest of Case Law on the United Nations Convention on Contracts for the International Sale of Goods UNCITRAL: Digest of Case Law on the United Nations Convention on Contracts for the International Sale of Goods - 2012 UNITED NATIONS 2012 Edition). 